\title{
Fiscal and Financial Policy Design on Entrepreneurial Economic
}

\section{Development Government Supports}

\author{
Zhen Lin ${ }^{1}$, Yunsheng Huang ${ }^{2}$ \\ ${ }^{1}$ North China University of Water Resources and Electric Power, Zhengzhou, China \\ ${ }^{2}$ North China University of Water Resources and Electric Power, Zhengzhou, China \\ 1email: linzh521@126.com \\ 2email: 522734686@qq.com
}

Key words: Entrepreneurial Economy, Fiscal Policy, Financial Policy

Abstract: In the process of entrepreneurial economic development, government can adopt legal tools, public goods and public services, economic policies, administrative tools and other multi-policy instruments to promote the development of entrepreneurial economy. This thesis designs the fiscal and financial policies for economic policy, adjust the fiscal and financial policies of middle and small-sized enterprises which exist shortcomings in the original coverage, sustainability, pertinence and availability, motivate the entrepreneurial driving force of whole society, make entrepreneurship become a main engine to promote economy for developing sustainably and then achieve a fundamental shift in the economic development model.

Throughout the development of global middle and small-sized enterprises, in addition to self-accumulation, its capital source depends mostly on capital market financing and government reducing taxes. Therefore, if a country wants to develop entrepreneurial economy and keep the sustainability and stay steady of middle and small-sized enterprises, this country should create a good survival and developing space for these enterprises through adjusting fiscal policy, financial policy and industrial policy, and then promote greater contributions for national economic development.

Middle and small-sized enterprises accounted for $99 \%$ of the total enterprises in our country, and their contribution rate to the economic development accounted for $60 \%$, taxes accounted for more than $50 \%$ of the total national revenue. Besides, they make greater contribution to employment, solving $80 \%$ employment of our country. SMEs also are the most dynamic group during the process of the entrepreneurial economy development. Furthermore, they are the main platform of science and technology innovation, which undertake more than $80 \%$ of new product development, $75 \%$ of technological innovation, $65 \%$ of patents in our country. Whether middle and small-sized enterprises can develop in a good state or not, which has a bearing on the trend of China's entrepreneurial economic development and economic sustainable development and more importantly becomes a vital part of adjusting economic structure and transforming economic growth pattern.

On a short view, the survival environment of middle and small-sized enterprises in China is not going well. In the aspect of financing, it shows that financing is difficult and expensive. The loan middle and small-sized enterprises receive from formal financial institutions accounts for less than 20 percent of the total loans, while the loan state-owned enterprises receive accounts for 80 percent of the loan amount from financial institutions though they accounts for 40 percent of contribution 
rate for economy. Commercial Banks generally promote margin share of acceptance of draft and make the actual interest nearly increase to double, and most folk financing cost is over three times higher than bank benchmark interest rate. In the aspect of tax, the actual tax burden of middle and small-sized enterprises generally is more than 30 percent of its profit. In addition to legal tax, middle and small-sized enterprises need to bear some expense which is influenced by the administration, such as, conference fees, association fees, rating fees, donations and subscribe to newspaper and periodicals and others, so its burden is very heavy. In the long run, it is very important to adjust the fiscal and financial policies of middle and small-sized enterprises which exists shortcomings in the original coverage, sustainability, pertinence and availability.

\section{Fiscal Policy Design}

The government increases investment in scientific research, improves country's supplying capacity of high technology industrialization and improves allocative efficiency of science and technology entrepreneurship resources through allocating financial resources. Furthermore, the government reduces the operating cost of entrepreneurial enterprises and high technology entrepreneurial enterprises and lowers the risks by implementing tax incentives policies. Fiscal policy mainly adopts budgeting, budget appropriation, government procurement, tax expenditure, fiscal investment and financing, subsidy, social insurance, government rewards and other measures to establish correspondingly fiscal supporting system and guide entrepreneurs to start a business in the field of technology-intensive, labor- intensive and others. Especially, more encouragement, support and assurance are given to those high-end entrepreneurial activities in the field of high-technology. Specifically, the government will arrange fiscal expenditure reasonably and use the budget appropriation to establish and improving public facilities of high technology and improve the government supplying capacity for high-tech industrialization when the government draws up state budget. The government increases the investment for entrepreneurship education train and promotes entrepreneurship skills. The government carries out tax preference and tax incentives for entrepreneurial enterprises and high technology industry to reduce entrepreneurial costs and reduce business risks. The opportunity of fair competition and relative equal competition environment of middle and small-sized enterprises in the business which are from government procurement and contract will be guaranteed by specifying the proportion of procurement for middle and small-sized enterprises in the process of government procurement. The government offers financial support for high-technology and high-end entrepreneurship through policy-based financial institutions in the way of fiscal investment and financing. In addition, the government provides relative good social insurance and reduces the all kinds of trouble for entrepreneurs by accelerating improvements in the social security system. Lastly, strengthen social affirmation for entrepreneurs through the government rewards.

\section{The Adjustments of Tax Policy}

Entrepreneurial enterprises, especial for high-technology entrepreneurial enterprises have the characteristics of high investment, high risks, high yields and so they are faced with huge market risk, development risk, loss risk of technology and other risks. However, China's current tax policy will reduce some tax for the profit that is from new product of enterprise technology development and there lack more consideration for tax for all kinds of tax categories from enterprises, investment for scientific research development and possible failure in the process of development. To a great degree, this will block technological innovation of enterprises. 
From the standpoint of being good for entrepreneurial enterprises birth, cultivation and development, preferential tax policy which follows the line of reducing the heavy burdens will be formed just for middle and small-sized enterprises. The main tax deduction and exemption as follows:

\section{Income Tax Deduction and Exemption}

At early stage of development, entrepreneurial enterprises can exempt income tax within three years, realize breakeven and reinvestment for offset, significantly improve tax exemption amount for the income tax of middle and small-sized enterprises and middle and small-sized enterprises of high and new technology or levy a half of tax and adopt preferential tax rate for the income tax of middle and small-sized enterprises to really reduce the income tax burden of middle and small-sized enterprises.

\section{Added-value Tax Deduction and Exemption}

In the period of Starting and growth, added-value tax deduction and exemption or tax reduction for half of applicable tax rate should be used for middle and small-sized enterprises, especial for small-scale taxpayers. The tax of fixed assets of entrepreneurial enterprises and new high-tech enterprises will be deducted before taxation so as to reduce the tax-setting amount of added-value $\operatorname{tax}$.

\section{Business Tax Deduction and Exemption}

Exempt business tax for entrepreneurial enterprises and new high-tech enterprises can change over from the cutoff point of business tax to tax exemption amount and raise tax exemption amount for business.

\section{Tariff Deduction and Exemption}

Lift business categories restrictions of export rebates for entrepreneurial enterprises and new high-tech enterprises and improve the strength of tax rebates through following the unitive tax rebates standard for tax reimbursement.

\section{Accelerating Depreciation:}

Increase the depreciation rate of purchasing production equipment for entrepreneurial enterprises and new high-tech enterprises, accelerate them to depreciate and then reduce the income tax of middle and small-sized enterprises.

\section{Deduction and Exemption for Entrepreneurial Investment Income}

Lower the capital gains tax, encourage entrepreneurial investment for low income area and carry out tax credit for their investment income tax.

\section{Tax Incentives for Specific Areas}

As for the entrepreneurial investment of agriculture, forestry, animal husbandry and fishery and poor and remote areas, in the early stage, enjoy relative tax reduction and exemption for a long time and in the sable period, enjoy the preferential rate.

\section{The Owner of Scientific Research Achievements}

On the part of transferring achievements, the income of entrepreneurial technology transfer or activities with a close relation for this part, such as, technical consultation, technical training and other activities can exempt business tax and income tax. As for individual income tax amount of personal technology transfer, adopt the policies that reduce or exempt preferential tax rate so as to let research staff for scientific and technological achievements find out more tangible benefits and then stimulate their enthusiasm. 


\section{The Buyers of Achievements in Scientific Research}

Allow the fees for buying achievements in scientific research to deduct added-value tax before tax, give favorable income tax for the gains from achievements in scientific research which are used and bought and stimulate enthusiasm for buying achievements in scientific research in the market.

\section{Adjustment of Tax Incentives}

Turn the privileges only for direct annual ring into mainly dominated by privileges in the step of researching and developing and meanwhile give a consideration for the privileges only for annual ring. Adjust the privileges only for production and trade enterprises into only for innovative and industrial supporting system tax. Regard the tax privileges of commercial research and development as important means of developing high and new technology industry and then promote the commercialization of the achievements in scientific research.

Roundly Design Relevant Tax Policy of Research and Development Activities for Different Stages.

In practical terms, as for the tax policy of experimental stage, pilot stage and industrialization stage, the tax policy of encouraging the technology import and digestive absorption and others. From the form of tax privileges, the scope and range of tax base privileges should be enlarged. As for enterprises which conduct research and development activities, if they meet the precondition of tax base privileges, they can enjoy relevant tax privileges treatment rather than view the income and profit from research and development activities as evaluation criteria.

\section{Fiscal Funding for Entrepreneurship Program}

Most of the commercial capitals are reluctantly put into entrepreneurial activities, because of their own high risk and income uncertainty. Funds are very crucial for entrepreneurs to enter the market, especially the financial funds playing the necessary role. The early financial funds will directly improve entrepreneurs' capitals and resources endowment in the process of entering the market. This will help encourage more entrepreneurial activities.

Funding policies for start-ups are mostly applied to the high-tech fields, which can greatly motivate entrepreneurs already in the territory of high and new technology into the activities. The incentive effect of policy supporting and demonstration effect are remarkable. So the fiscal funding for the range of the target group may be extended appropriately, to make the target groups supported by fiscal funds more universal, to encourage more people to engage in entrepreneurial activities.

Considering on the limitations of public funds and incentive effect, free sponsorship should be just one of the modes of concrete support. Paid grants, low-interest loans, fiscal interest discount, etc. should also be comprehensively used. Free sponsorship can more be given priority to with microfinance funding approach. Part of startup project with the stable market outlook and good expected return can also be in the form of equity capital investment. The entrepreneurial enterprises and small and medium-sized enterprises can be given a certain proportion of fiscal subsidies to make up their research spending, for example, French government stipulates that investment subsidies should make up $25 \%$ of research spending. Interest-free loans through policy-based financial institutions can be provided, for example, the French government provide 200000 300000 francs interest-free loans with the payback period of $15 \sim 50$ years. Government funding can be provided with start-up companies in the form of preferential loans by some private financial intermediaries, such as small business Investment Company, like Japan, the US and other countries. Small and medium-sized enterprises can be organized to attend abroad exhibitions for free or low-cost. Or small and medium-sized enterprise representatives can be organized to make 
on-the-spot investigation abroad. Embassies economic counselor can help to contact with foreign for small and medium-sized enterprises. Some indirect and covert subsidies can be given.

\section{Government Procurement}

In a market economy, government, as an economic body, is a buyer with the strongest purchasing power for whole market. Therefore, to some extent, the concentrative purchase of government guides the developing direction of production and consumption for whole society. Many countries formulate supporting policy for government procurement of middle and small-sized enterprises. For example, when American government purchases, distribute all purchased product, include military material, to middle and small-sized enterprises with a certain scale. In Korea, there is a stipulation that government must give priority to purchasing products of middle and small-sized enterprises which carry out the "performance certification" and "property insurance" so as to improve the market competitiveness of products for middle and small-sized enterprises and broaden its market. In UK, in order to support middle and small-sized enterprises to obtain government procurement, government has written <the handbook of middle and small-sized enterprises take part in government procurement activities> so as to give middle and small-sized enterprises for all-around guidance.

\section{Fiscal Technology and Education Expenditure}

Fiscal fund plays a crucial role in the development of scientific undertakings and educational business. The sustained and healthy development of science and education career not only enhances the level of whole science and promotes the progress of science and technology, but also can cultivate high-caliber and high-skill entrepreneurial talents and improve the quality of the labor force. Gradually set up fiscal science and technology investment mechanism that increases steadily, ensure the growth of fiscal science and technology investment to surpass the growth of fiscal regular revenues. In order to accelerate entrepreneurial economic development, promote entrepreneurial social construction and provide the powerful expenditure guarantee. Optimize the structure of fiscal science and technology investment and then reasonably collocate scientific and technological resources.

\section{Establish Guiding Fund for Entrepreneurial Investment and Guaranteed Fund for Entrepreneurial Enterprises}

The main purpose for establishing guiding fund for entrepreneurial investment is to assist the development of entrepreneurial investment enterprises to drive social capital for entrepreneurial investment and increase the supplies for entrepreneurial investment capital. The capital source of guiding fund for entrepreneurial investment includes fiscal special fund, investment income of guidance fund, fund freely donated by individuals, enterprises or social institutions and others. Constantly enrich and enlarge fund capacity, increase investment and fully embody its policy tendency and guiding intention. Strengthen the scientific management and make the entire guiding fund having a job and then create maximum guiding positive effect. According to the operation situation of new entrepreneurial enterprises, financial support will be provided duly. Government in character as the investor participates in entrepreneurial enterprises and supports entrepreneurial enterprises financing with the method of participation in certain stage.

Fiscal investment establishment which is only for guaranteed fund of entrepreneurial enterprises, provides security for entrepreneurial enterprises financing in order to solve the financing difficulties for entrepreneurial enterprises in startup phase. 


\section{Entrepreneurial Subsidy and Social Insurance}

The early period of entrepreneurship is a stage when entrepreneurs meet most difficulties, not only including many difficulties related to career development and but also cannot avoid the pressure from life. It is indispensable for entrepreneurs to increase necessary subsidies and insurance. For example, encourage entrepreneurs to conduct entrepreneurial activities, reduce entrepreneurs' living burden in the early period by providing entrepreneurial Subsidy for entrepreneurs and then create a relevant loose environment.

As for entrepreneurs, entrepreneurship is a high risk and uncertain activity. Entrepreneurship failure is different from general unemployment and its consequence may be worse, will even affect entrepreneurs' whole life. So, to some extent, providing entrepreneurs a relevant favorable living guarantee can relieve entrepreneurs' worries and undoubtedly, it is also an important element with great effect for entrepreneurs. For instance, in the early period of entrepreneurship, when contribute the social insurance "Three Gold" and "Five Gold", letting low individual contribution proportion enjoy equivalent social insurance. When the enterprises are in stable stage, entrepreneurs contribute "Three Gold" and "Five Gold" by the normal standard. As for those entrepreneurs who ever had failed experiences for various reasons, nation can give certain entrepreneurial subsidy to reduce their living pressure.

\section{Financial Policy}

Financial policy which promotes entrepreneurship is still a key point for entrepreneurial policy. Capital source is one of biggest problems that perplex entrepreneurial economic development. In the process of entrepreneurship, knowledge and technology are very important, but if turn knowledge and technology into productivity, the capital will be required to set up enterprises, employ staff and carry out management activities and technological innovation activities for production organization. However, at present, entrepreneurs encounter great difficulties of financing and mainly reflect in complex loan procedure, requirement for relevant property mortgage or guarantee and strict limitation for loan amount. If government wants to solve this problem, government should formulate relevant policies to constantly improve entrepreneurs' financing environment, broaden entrepreneurs' financing channel and meet capital requirement of entrepreneurship. (Lin Zhen, 2011)

Financial policy instrument is divided into direct financing policy and indirect financing policy. In the aspect of direct financing, improve second board market and middle and small-sized enterprises board market and lower the standard for coming to market of entrepreneurial enterprises. Standardize private investment and guide private investment into entrepreneurial activities. Guide the flowing direction of entrepreneurial investment, encourage angel investment, risk funds, private equity funds and others to enter entrepreneurship area and then eliminate capital "bottleneck" of high technology entrepreneurial enterprises development. In the aspect of indirect financing, mainly establish loaning bank of middle and small-sized enterprises, loan policy with low interest, loan policy with fiscal discount, petty loan policy, investment guarantee policy, loan guarantee policy of entrepreneurial enterprises and others, increase entrepreneurs' financing opportunity, reduce entrepreneurs' financing cost and provide finance support.

\section{Standardize Endogenous Financing of Middle and Small-sized Enterprises}

Financing channels of middle and small-sized enterprises and mainly come from interior because of lacking historical honesty record system and full dose property mortgage. Endogenous financing which refers to entrepreneurs' personal contribution, relatives and friends' debit and credit, 
self-accumulation of enterprises' development and others, is a main financing channel of middle and small-sized enterprises. From the angle of western countries' situation, the proportion endogenous financing occupies reaches to 40\% 50\%. Envisage endogenous financing, fully ensure positive function of endogenous financing for small enterprise development and then regard this as reasonable and popular small enterprise financing channel. But, large randomness of endogenous financing, informal interest rate, large prepayment risk and others cannot be avoided. Firstly, actively promote credit inquiry of middle and small-sized enterprises and reduce the risk of endogenous financing. Secondly, effectively reduce the risk of the borrowers through doing guarantee and re-guarantee of endogenous financing and risk preparatory work.

\section{Develop Bond Financing}

The bond market development in China is not insufficient. At present, large enterprises and financial institutions can issue bonds in bond market and middle and small-sized enterprises are not allowed to issue bonds. Compared to bank credit, there are many the merits of bond financing. The first is wide capital source. Bond financing source is extensive social capital and can meet a large number of financing requirement of middle and small-sized enterprises. The second is low implicit cost. Middle and small-sized enterprises which obey standard procedure and meet the conditions are eligible to apply for bond financing. The third is flexible financing methods. It is ok both for single enterprise to finance by issuing bonds and a few enterprises to finance together by issuing bonds. The fourth is the rate with great flexibility. Bonds adopt flexible rate without ceiling limitation of bank loan and can attract social capital purchase. Issue high-yield bonds, collective bonds and others, and these financing methods suit small and micro enterprises. Issue high-yield bonds for specified objects and publicly issue collective bonds for whole market to increase the mobility of bonds.

\section{Innovate Financing Institution}

Develop middle and small-sized local financial institutions of private capital which accelerate entrepreneurship, such as small enterprises bank or small-scale loans enterprises. The scale of these institutions is small and the scope of business is limited. But these institutions, having a better understanding for local economy, on target not only provide more financial support for middle and small-sized enterprises in the process of entrepreneurship, but also effectively guide reasonable flowing direction of private capital, reduce lose which is brought by reason of information asymmetry in the process of debit and credit and enhance the security of loan.

Establish guarantee institutions of entrepreneurial enterprises with policy support provide guarantees and warranties for entrepreneurial enterprises to improve financing dilemma of entrepreneurial enterprises. Regarding guarantee institutions as main body and regarding commercial bank network as foundation further improve multi-level credit guarantee system, push out convenient loan channels and accelerate rapid development of entrepreneurial enterprises.

\section{Small-sized Guarantee Loan policy}

At present, small-sized guarantee loan is a kind of new financial products which are pushed out by a few financial institutions. The procedure of this kind of patterns of loaning is very simple, flexibly loan, repay conveniently, loan with greater proportion. In the aspect of guarantee, it is very flexible and can provide property mortgage, individual credit guarantee and others. In the developing process of entrepreneurial enterprises, this kind of loan can meet the requirements of enterprises for fund and help enterprises through operational difficulties. Broaden supporting range of small-sized guarantee loan. Expand supporting range of small-sized guarantee loan from employers of original state-owned enterprise to college graduates who set up one's own businesses 
and migrant workers who go back hometown for entrepreneurship. In addition to industries with nation's limitation, entrepreneurial projects will be provided relevant interest subsidy by employment fund. In addition, as for middle and small-sized enterprises, they can adopt mortgage pattern of intellectual property to enhance the loan limit of middle and small-sized enterprises so as to provide maximal loan supports for entrepreneurial economic development.

\section{References:}

[1] Li Mei. Entrepreneurial Economy: Memory Mechanism and Development Strategies [M]. Beijing: social sciences literature press, 2010

[2] Zhang Monan. Entrepreneurial economic theory [M]. Beijing: People's Publishing House, 2009

[3] Acs,Z. J. ,Audretsch,D. B.,Carlsson P. B. The Missing Link: The Knowledge Filter and Entrepreneurship in Endogenous Growth[R].Center for Economic Policy Research, Discussion Paper. 2004

[4] Chinese Vocational Educational Institute. Global Entrepreneurial Economy BBS Corpus [C]. Beijing: China Central Radio \& TV University, 2009

[5] Zhang Yuli. Entrepreneurs How to Integrate Resource?[J]. Management at home and abroad, 2011, (06)

[6] Zhang Yuli. Entrepreneur Team needs to Give Attention to Complementarity and Conflict [J]. Managerialist, 2010, (08) 